\title{
TLC Profiling of Leaves Extracts of Some Aloe Threatened Species Endemic to Madagascar for Their Antioxidant Activity
}

\author{
Rokiman Letsara ${ }^{1}$, Rigobert Andrianantenaina ${ }^{2}$, Gédéon Ngiala Bongo ${ }^{3}$, Colette \\ Masengo Ashande ${ }^{4}$, Mahendra Ilmi S Matondang, ${ }^{5}$, Koto-te-Nyiwa Ngbolua ${ }^{6}$, Baholy \\ Robijaona Rahelivololoniaina ${ }^{7}$ \\ ${ }^{1}$ Parc Botanique et Zoologique de Tsimbazaza, Antananarivo, Madagascar \\ 1,7Engineering and Industrial Process, Agricultural and Food Systems, Polytechnic High School of \\ Antananarivo, Antananarivo, Madagascar \\ 2National Centre of Environment Research, Antananarivo, Madagascar \\ 3,4, Department of Environmental Sciences, Faculty of Science, University of Gbado-Lite, Gbado-Lite, \\ Democratic Republic of the Congo \\ ${ }^{5}$ Department of Biotechnology, FBIM, Universiti Sultan Zainal Abidin, Kuala Terengganu, Malaysia \\ ${ }^{6}$ Department of Biology, Faculty of Science, University of Kinshasa, Kinshasa, Democratic Republic of \\ the Congo \\ Email: holyrobi@gmail.com
}

\begin{abstract}
:
The World Health Organization reported that at least $80 \%$ of populations rely on traditional medicine and medicinal plants for their primary health care. Due to their phytochemical compounds, the plants of the Aloe genus are reported to have high potential antiCovid-19 (and antioxidant properties. The aim of this study is to evaluate the in vitro antioxidant activity of some Malagasy endangered species of Aloe genus. The ethanolic extract of few Aloe of Madagascar leaf extracts was fractionated by liquid-liquid partition using hexane. In total 18 different fractions from 9 species have been used to determine their antioxidant activity through in vitro model by using 2,2-Diphenyl-1-picrylhydrazyl (DPPH) assay. Both hexanic extract and aqueous extract displayed antioxidant activities in four species. The most evident antioxidant activity was expressed by A. helenae.
\end{abstract}

Keywords:

antioxidant properties; aloe spp.; conservation; Madagascar

\section{Introduction}

The World Health Organization (WHO) reported that at least $80 \%$ of populations rely on traditional medicine and medicinal plants for their primary health care (Ngbolua et al., 2011a, b; Ngbolua et al., 2016a). The use of medicinal plants for various health problems is not only a choice but is also linked to poverty due to and the high costs of modern medicines (Ngbolua et al., 2016b; Inkoto et al., 2018; Ngbolua et al., 2019a). In fact, the excess production of Oxygen Reactive Species (ORS) can become toxic to the major components of the cell and gives rise to oxidative stress, which will lead to numerous pathologies such as neurodegenerative diseases (Alzheimer, Parkinson), diabetes, cancer, inflammatory diseases, aging, etc. Cells use many antioxidant strategies to eliminate or minimize the oxidative damage (Iteku et al., 2019). These plants contain an arsenal of bioactive compounds like coumarins, flavonoids, terpenoids, alkaloids, tannins, etc. which are endowed with interesting and relevant pharmacological properties including antioxidant activity (Bongo et al., 2017). Aloe L. genus is a largely African genus having a major center in terms of diversity in South Africa and Madagascar, and it contains at least 624 species (Lindsey et al., 2003). 
Aloe colonized all major habitats in Madagascar from rainforests to high peaks of the central taxa highlands and the dry forests of the South (Orlando, 2013). It is a typical element of the succulent flora of the eastern Indian Ocean islands of Madagascar, the Mascarene islands of Mauritius, Reunion and the Seychelles (Dee et al., 2018). The same author reported 132 native Aloe spp., all of which are endemic to Madagascar and consider the island as a major center of diversity of Aloe. Aloes come in a variety of growth forms, from small miniatures to tall trees, and anything in between (Klopper, 2013). Apart from its morphological and geographical distribution heterogeneities, phylogenetic evidence showed (excluding Lomatophyllum morpho-group) a non-monophyletic unit in Malagasy Aloe spp (Dee et al. 2018) which leads to the difficulty of identifying them at the species level.

It has been known also for years pharmacological properties of Aloes in the world. Due to its phytochemical compounds, a non-native and extensively cultivated A. vera (L.) Burm.f. (syn.: Aloe barbadensis Miller) is reported to have high potential antiCovid-19 (Mpiana et al., 2020a, b) and antioxidant properties (Miladi et al., 2008). The aim of this study is to fill the gap in phytochemical studies of Malagasy endangered species of Aloe genus by testing in vitro its antioxidant activity.

\section{Research Method}

\subsection{Plant Material}

Different species used in this research and its conservation status are presented in table 1 below.

Table 1. List of Malagasy Endangered Species of Aloe Genus

\begin{tabular}{|c|c|c|}
\hline Plant species & Used material & Conservation Status \\
\hline $\begin{array}{l}\text { Aloe capitata var angavoana J.- } \\
\text { P.Castillon }\end{array}$ & $\begin{array}{l}\text { Leaf powder } \\
\text { extract }\end{array}$ & $\begin{array}{c}\text { Endangered } \\
\text { (Rakotoarisoa et al., } \\
\text { 2014) }\end{array}$ \\
\hline $\begin{array}{l}\text { Aloe capitata var quartziticola } \mathrm{H} \text {. } \\
\text { Perrier }\end{array}$ & $\begin{array}{l}\text { Leaf powder } \\
\text { extract }\end{array}$ & $\begin{array}{c}\text { Endangered } \\
\text { (www.geocat.kew.org, } \\
2019 \text { modified) }\end{array}$ \\
\hline Aloe helenae Danguy & $\begin{array}{l}\text { Leaf powder } \\
\text { extract }\end{array}$ & $\begin{array}{l}\text { Endangered } \\
\text { (IUCN 3.1) }\end{array}$ \\
\hline $\begin{array}{l}\text { Aloe cipolinicola (H.Perrier) J.- } \\
\text { B.Castillon \& J.-.Castillon }\end{array}$ & $\begin{array}{l}\text { Leaf powder } \\
\text { extract }\end{array}$ & $\begin{array}{c}\text { Endangered } \\
\text { (Rakotoarisoa et al., } \\
\text { 2014) } \\
\end{array}$ \\
\hline $\begin{array}{l}\text { Aloe analavelonensis Letsara, Rakotoar. } \\
\text { \& Almeda }\end{array}$ & Fresh leaf extract & $\begin{array}{c}\text { Vulnerable (Letsara et } \\
\text { al., 2012) }\end{array}$ \\
\hline $\begin{array}{l}\text { Aloe ivakoanyensis Letsara, Rakotoar. \& } \\
\text { Almeda }\end{array}$ & Fresh leaf extract & $\begin{array}{l}\text { Critically Endangered } \\
\text { (Letsara et al., 2012) }\end{array}$ \\
\hline Aloe suzannae Decary & Fresh leaf extract & $\begin{array}{l}\text { Endangered } \\
\text { (IUCN 3.1) }\end{array}$ \\
\hline Aloe suarezensis H. Perrier & Fresh leaf extract & $\begin{array}{c}\text { Endangered } \\
\text { (Rakotoarisoa et al., } \\
\text { 2014) }\end{array}$ \\
\hline Aloe guillaumetii Cremers & Fresh leaf extract & $\begin{array}{c}\text { Critically Endangered } \\
\text { (Rakotoarisoa et al., } \\
\text { 2014) }\end{array}$ \\
\hline
\end{tabular}


Biological materials (mainly fresh leaves) were provided by Tshimbazaza Zoological and Botanical Park between January and May 2019. They were added along with the author personal living collections. To make the powder of collected leaves, about $100 \mathrm{~g}$ of different species (A. capitata var angavoana, A. capitata var quartziticola, A. helenae and A. cipolinicola) and (A. analavelonensis, A. ivakoanyensis, A. suzannae, A. suarezensis and A guillaumetii) (Figure 1) collected in January and May respectively was preserved in a freezer at $-20{ }^{\circ} \mathrm{C}$. Afterwards, these leaves were dried by lyophilization (Temperature $-40{ }^{\circ} \mathrm{C}$ under pressure $0,850 \mathrm{mBar}$ during 24 hours), then, grounded in order to make a fine powder. For each species $10 \mathrm{~g}$ and $15 \mathrm{~g}$ of powder was used for extraction respectively.
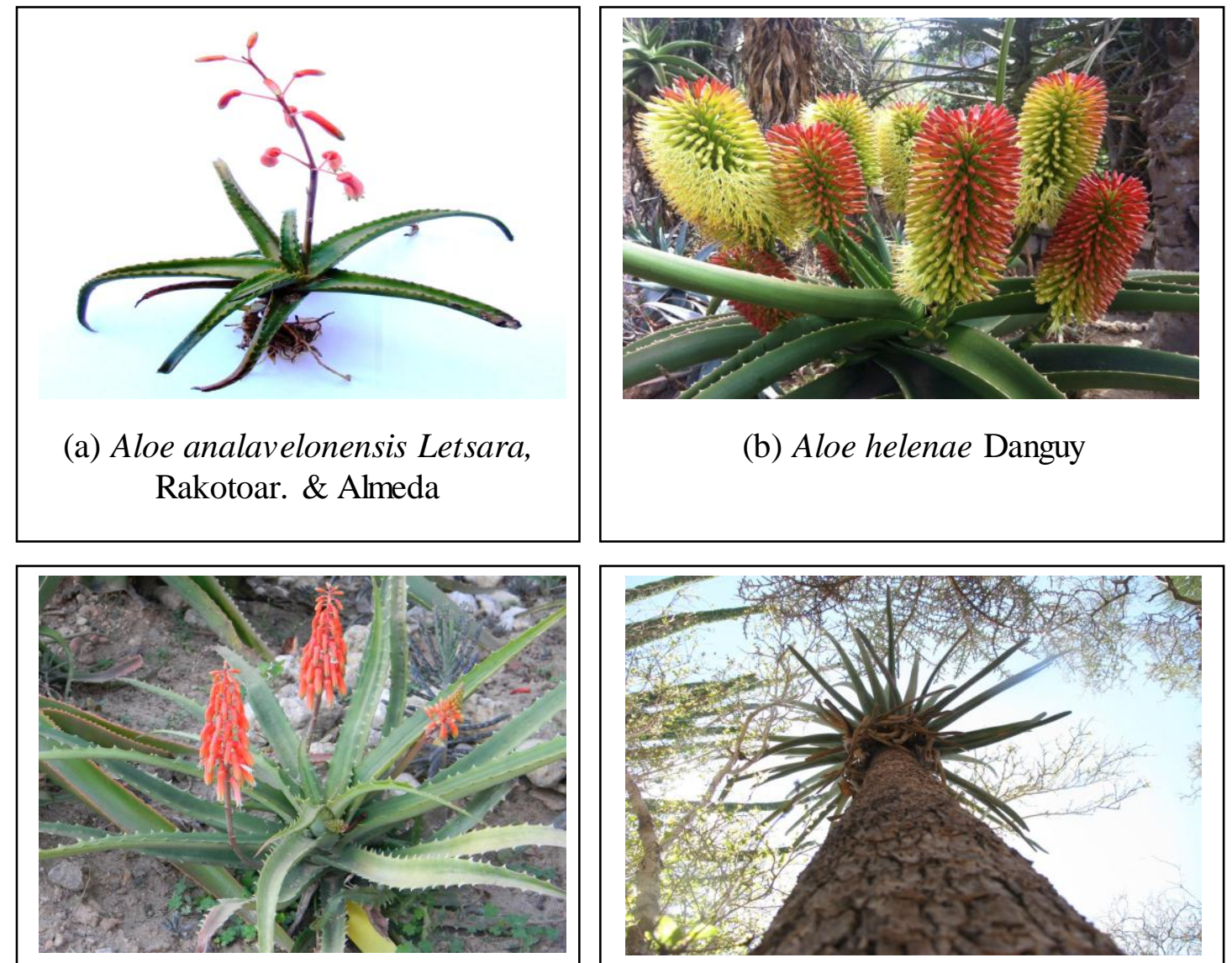
(c) Aloe ivakoanyensis Letsara,
Rakotoar. \& Almeda

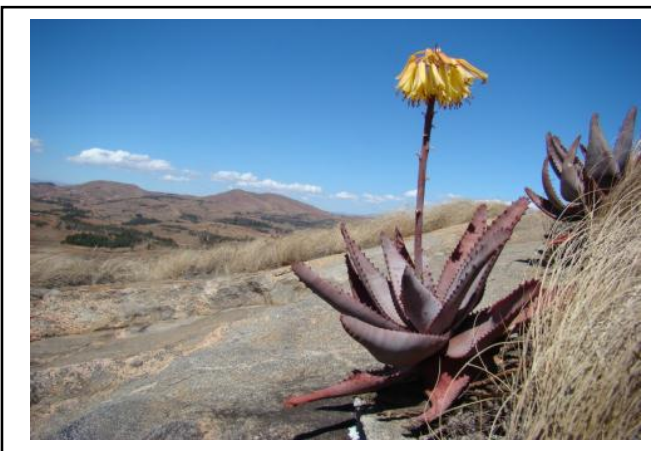

(e) Aloe capitata var quartziticola H. Perrier

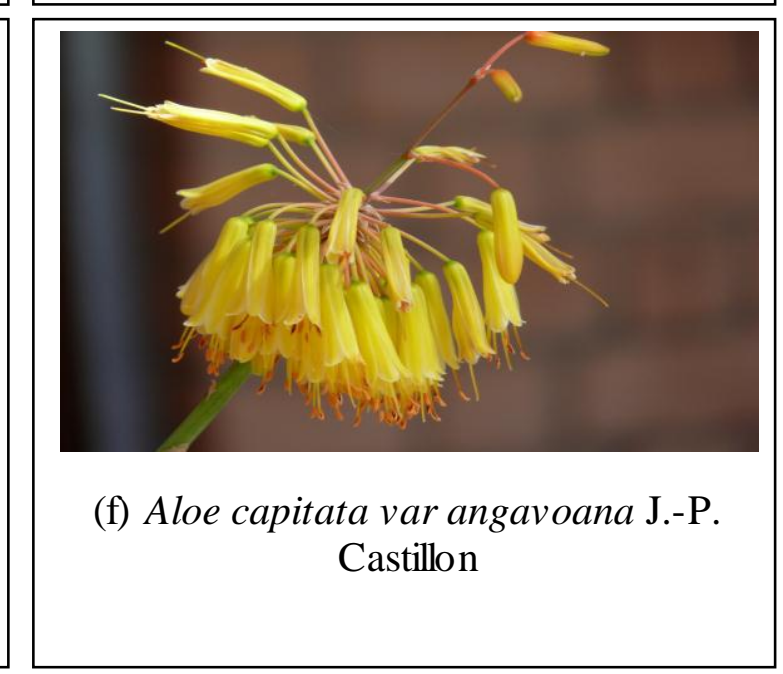




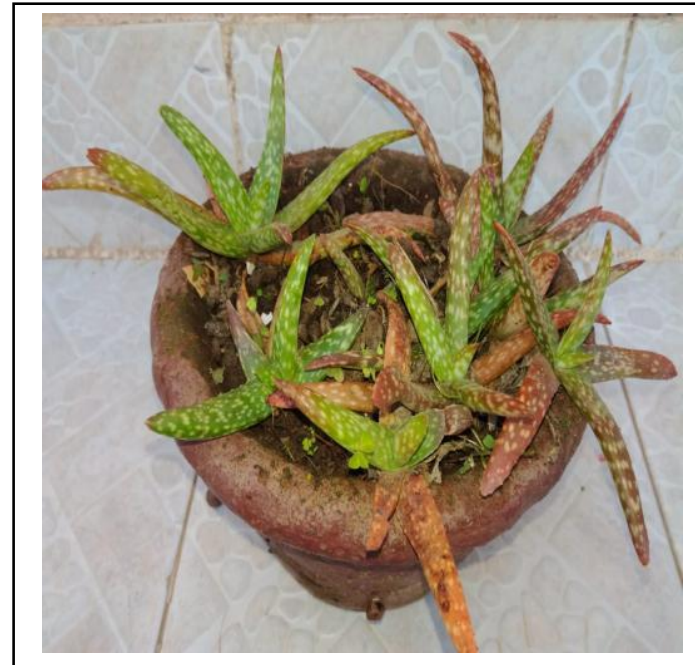

(g) Aloe guillaumetii Cremers

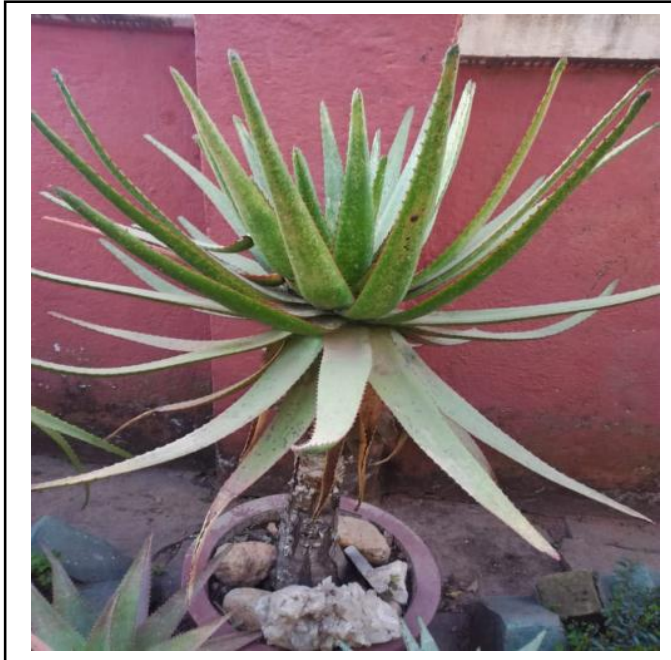

(h) Aloe cipolinicola (H.Perrier) J.B.Castillon \& J.-.Castillon

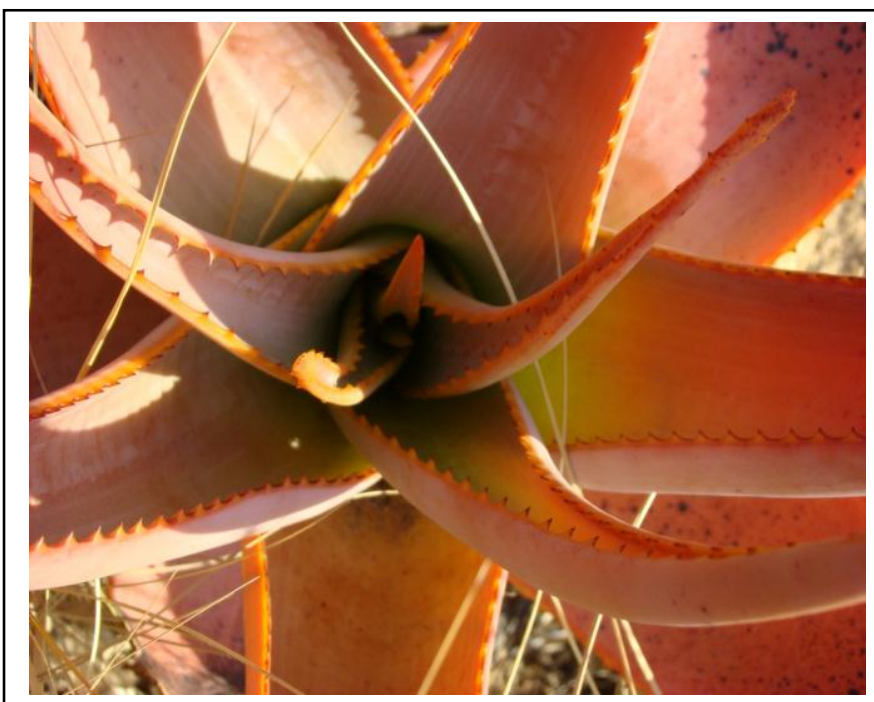

(i) Aloe suarezensis $\mathrm{H}$. Perrier

Figure 1. Picture of Malagasy endangered species of Aloe genus

\subsection{Extract Preparation}

Each fresh material and powder was extracted with $100 \mathrm{~mL}$ of ethanol $80^{\circ}$ at a temperature $70^{\circ} \mathrm{C}$ for 1 hour. After filtration, the ethanol was evaporated under pressure at 45 ${ }^{\circ} \mathrm{C}$ for about 20 minutes. The obtained extract was then de-pigmented by Hexane and the quantity of the solvent used depended on samples. Afterwards, two phases were obtained namely: n-hexane soluble fraction and aqueous extract separately. The $n$-hexane soluble fraction was evaporated to have more concentrated solution and at last $10 \mathrm{~mL}$ of each extract were collected (figure $2 \mathrm{a}, \mathrm{b}$ ). 


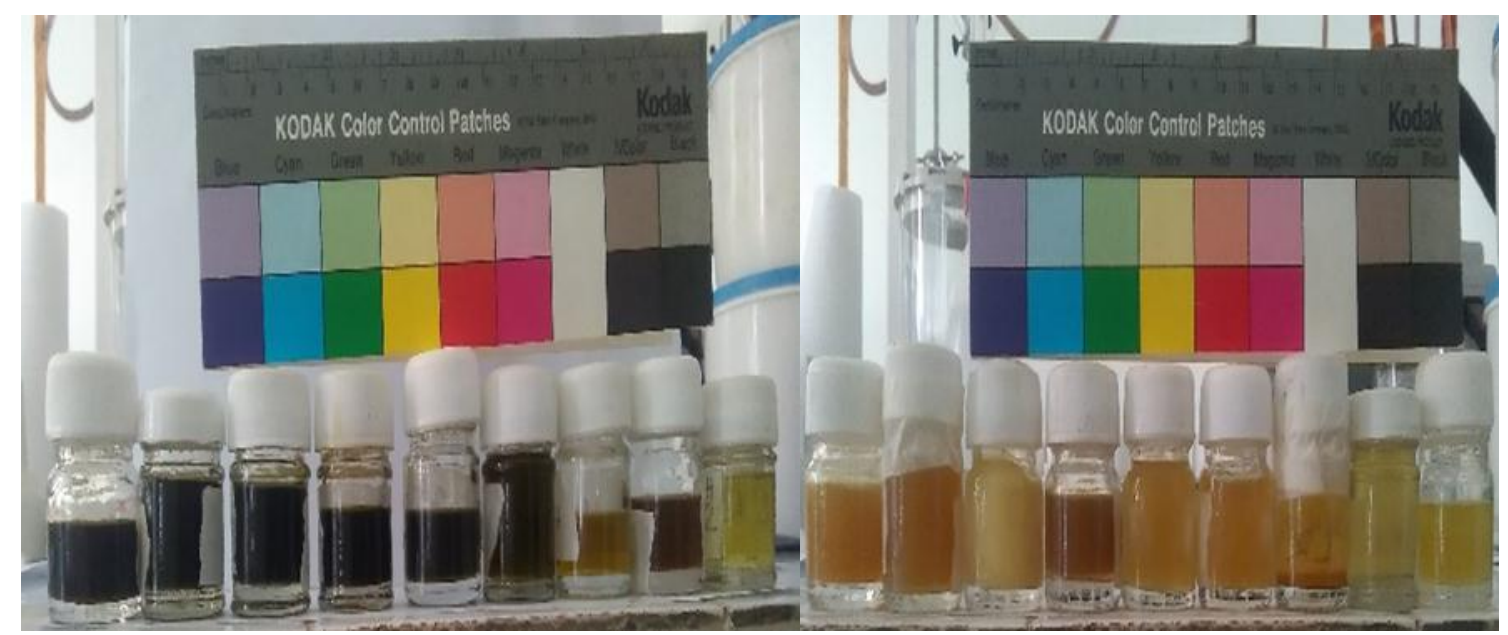

Figure 2a. Concentrated n-hexane extract

Figure 2b. Aqueous extract

\subsection{Determination of Antioxidant Capacity}

This method is based on the degradation of DPPH radical (2, 2 DiPhenyl-1PicrylHydrazyl). The DPPH radical is a violet-colored radical; the addition of antioxidant reduces this radical and causes the mixture to discolor. This radical decolorization measured by spectrophotometer at $517 \mathrm{~nm}$ is proportional to the concentration of antioxidants (Bongo et al. 2017). The antioxidant activity of the separated extracts was estimated in terms of hydrogen-donating or radical scavenging ability, using the 2, 2-Diphenyl-1-picrylhydrasyl (DPPH) method in the TLC plate (Brand-Williams, 1995). A coloration change will show the antioxidant activity in the soaked plate by the DPPH. The presence of antioxidant capacity of the extract was estimated visually after TLC at room temperature. The following solutions were combined to make the eluent: Hexane 1, Methane 9, ED 0.2 for separation of the extracts. The efficiency of the deposit, the migrations was controlled under UV $254 \mathrm{~nm}$ light.

\section{Results and Discussion}

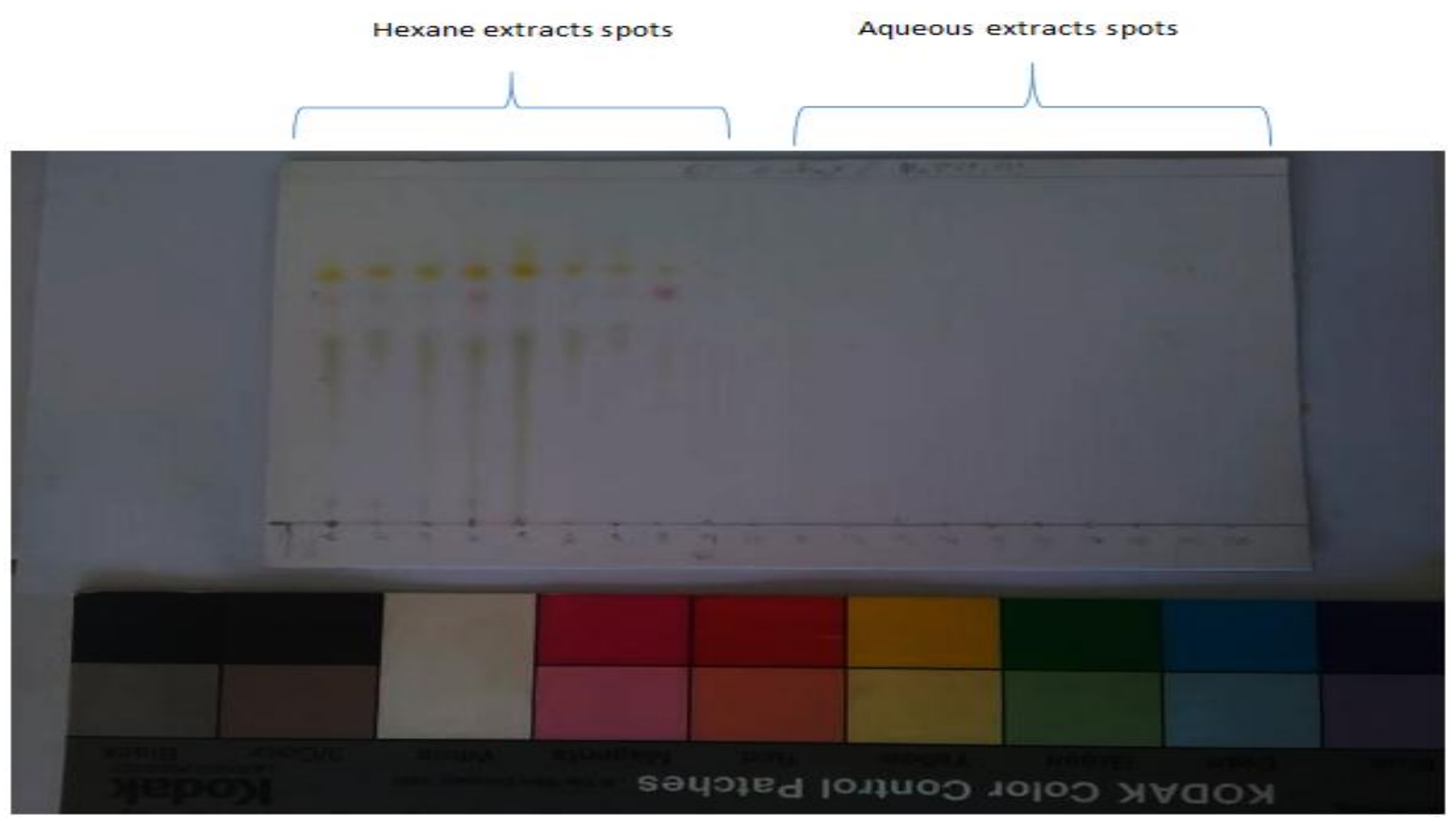

Figure 3a. Photo of TLC Spotted with 18 Sports after Migrations 
Unaided eye observation shows three different spots movement, yellow, purple and dark green mainly in the $n$-hexane extracts. This explains the separation of molecules that contains the extracts. On the other hand the observation under the UV lights showed more detailed images of the molecules migrations.

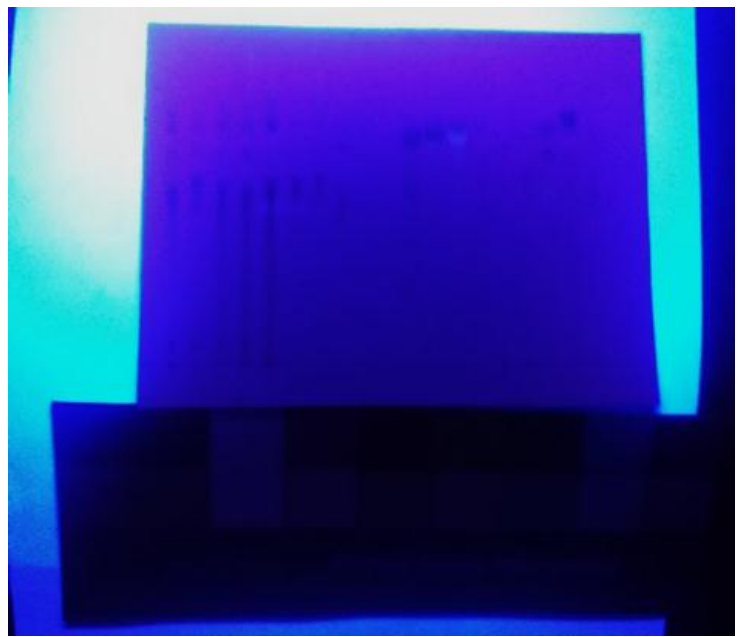

Figure 3b. TLC profiling under UV $254 \mathrm{~nm}$

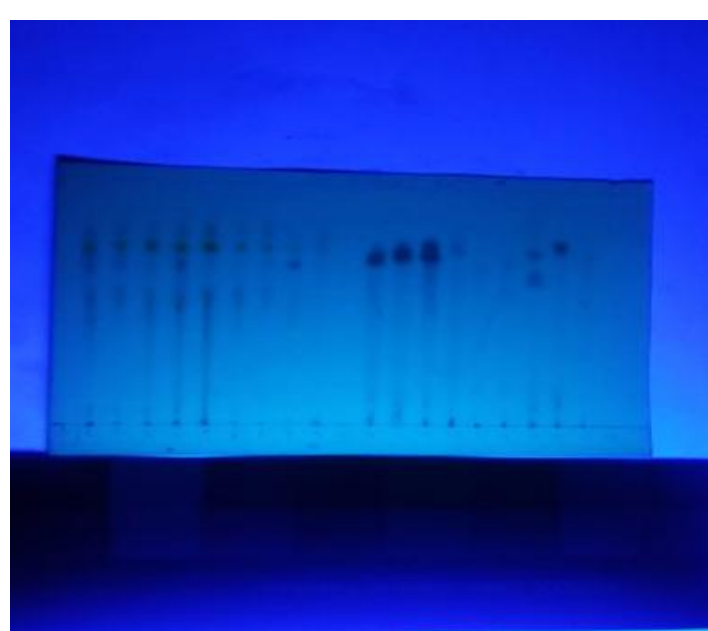

Figure 3c. TLC profiling under UV $365 \mathrm{~nm}$

Among those migrated molecules, some reacted with the DPPH radical and produced a yellowish spot, which could be explained by an antioxidant activity. Its reaction was expressed by the following figure.

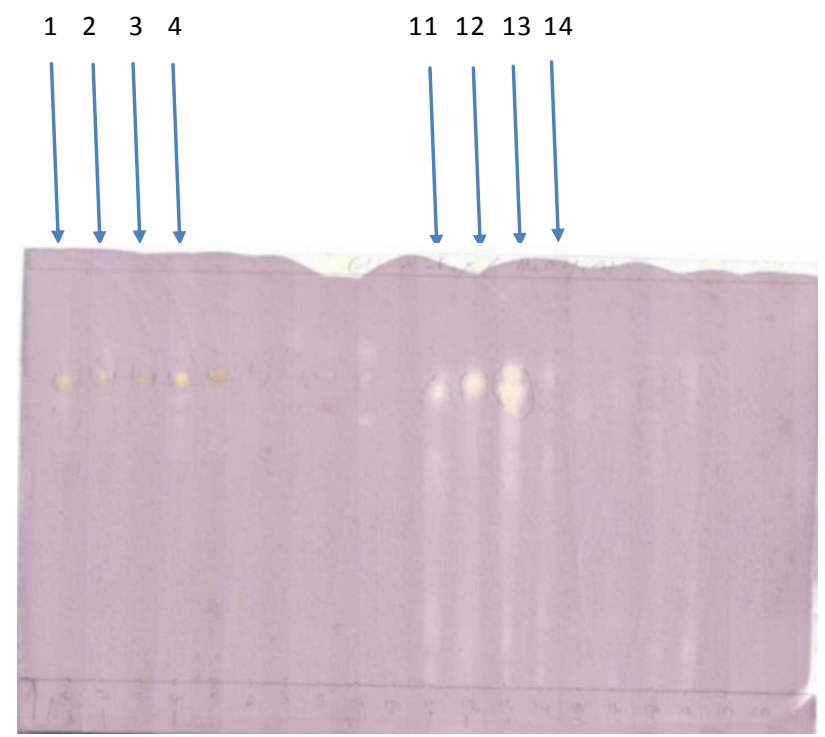
(1) Hexanic extract spot of Aloe capitata var angavoana
(2) Hexanic extract spot of Aloe capitata var quartziticola
(3) Hexanic extract spot of Aloe helenae
(4) Hexanic extract spot of Aloe cipolinicola
(11) Aqueous extract spot of Aloecapitata varangavoana
(12) Aqueous extract spot of Aloecapitata var quartziticola
(13) Aqueous extract spot of Aloehelenae
(14) Aqueous extract spot of Aloecipolinicola

Figure 3d. TLC Spotted Plate Sprayed with DPPH Radical

The figure $2 \mathrm{~d}$ showed the TLC plate with migrated spots, which expressed antioxidant activity. They belong to the following species extracts: $A$. capitata var angavoana, $A$. capitata var quartziticola, $A$. belenae and $A$. cipolinicola. The most evident reaction is in the aqueous extract of leaf powder of $A$. belenae (spot 13). 
SARS-CoV-2 is the pathogen agent of the new corona virus disease that appeared at the end of 2019 in China. There is, currently, no effective treatment against COVID-19. Recent findings based on molecular docking study revealed that some Aloe derived compounds are potential inhibitors of the main protease (3CLpro) responsible for the replication of coronaviruses (Mpiana et al., 2020a). The present research revealed that the plant of the Aloe genus could serve as anti-oxidative therapy for ameliorating injuries of Covid-19-infected patients. It also was reported that some plants belonging to Aloe genus has a large abroad of antiviral activity on several types of virus (Haemorrhagic Viral Rhobdavirus Septicaemia, Herpes simplex virus type 1, Herpes simplex virus type 2, Varicella-Zoster virus, human immunodeficiency virus, Influenza virus, poliovirus, Cytomegalovirus, Human papillomavirus) including coronavirus SARS-CoV-1 and are consumed orally in several forms and are safe (Mpiana et al., 2020b).

Given the ethno-medical importance the plant species of Aloe genus for the population and their scientifically validated pharmacological properties, it is therefore desirable to develop sustainable strategies for the conservation of these species. One option to be explored is their domestication with a view to their use as material for drugs manufacture. Thus, the cultivation of Aloe congensis in agro-ecosystems in forest and savannah environments of Democratic Republic of the Congo (DRC), particularly in the Nord Ubangi Province, would allow a better comparative study with species from Madagascar, as is the case for some ongoing studies (Randrantoarimbola et al., 2020). This part of DRC belongs to the Ubangi eco-region, a subgroup of Northeastern Congolian lowland forests. This eco-region is one of the 200 globally priority terrestrial eco-regions known as the "G200" (Ngbolua et al., 2020a, b, Ngbolua et al., 2019b, c, d; Gbolo et al., 2019; Ngunde-te-Ngunde et al., 2019).

\section{Conclusion}

The findings of this research showed that there are nine endangered species of Aloes in Madagascar. The TLC profiling revealed that four species showed traces of antioxidant activity. The anti-oxidative reaction was different depending on the nature of the extract (from powder or fresh) and plant species. A very characteristic reaction was shown in the aqueous extract of leaf powder of A. helenae. Research is in progress to isolate and identify the antioxidant compounds in those fractions.

\section{Acknowledgements}

The authors thank Dr Franck Rakotonasolo, responsible of the living collections at the PBZT, for his assistance collecting the living specimens in the wild and access to some fresh materials from the garden. They also appreciate the Centre National de Recherches sur l'Environnement (CNRE) authorities for giving permission to carry out experiments in their lab. 


\section{References}

Bongo, G., Tuntufye, H., Ngbolua, K.N., Malakalinga, J., Claudine, T., Pambu, A., Mwanza, F., Mbadiko, C., Makengo, G., Tshilanda, D., Mpiana, P., Mbemba, T., Kazwala, R. (2017). Comparative Antimycobacterial Activity on Lowenstein-Jensen Slants of Selected Medicinal Plants Used in the Congolese Pharmacopeia. Journal of Diseases and Medicinal Plants, 3(5), 88-96. doi: 10.11648/j.jdmp.20170305.12

Brand-Williams, W., Cuvelier, M. E., Berset, C. 1995. Use of a Free Radical Method to Evaluate Antioxidant Activity. Lebensm. Wiss. Technol. 28, 25-30.

Castillon, J.-B. (2010). Les Aloe de Madagascar. ISBN: 978-2746618729.

Dee, R., Panagiota, M., Olwen, M.G. (2018). A phylogenetic analysis of the genus Aloe (Asphodelaceae) in Madagascar and the Mascarene Islands. Botanical Journal of the Linnean Society, 187(3), 428-440.

Gbolo, Z.B., Ngbolua, K.N., Mpiana, P.T., Ndanga, B.A., Pangodi, A.J.M., Masengo, A.C., Mudogo, V. (2019). Evaluation of the Clinical Efficiency of an Antisickling Polyherbal Formula Drepanoalpha in a Sickle cell disease Patient in Gbado-Lite City (Democratic Republic of the Congo) by Quantum Magnetic Resonance Analyzer. Britain International of Exact Sciences (BIoEx) Journal, 1(1), 36-48. http: / /www.tropicalplantresearch.com/archives/?year $=2016 \& v o l=3 \& i s s u e=2 \&$ Articl eId $=135$.

Inkoto, L.C., Bongo, N.G., Kapepula, M.P., Masengo, A.C., Gbolo, Z.B., Tshiama, C., Ngombe, K.B., Iteku, B.J., Mbemba, F.T., Mpiana, P.T., Ngbolua, K.N. (2018). Microscopic features and chromatographic fingerprints of selected congolese medicinal plants: Aframomum alboviolaceum (Ridley) K. Schum, Annona senegalensis Pers. and Mondia whitei (Hook.f.) Skeels. Emergent Life Sciences Research, 4(1), 1-10.

Iteku, J.B., Mbayi, O., Bongo, G.N., Mutwale, P.K., Wambale, J.W., Lengbiye, E., Ngunde, S.N., Ngbolua, K.N. (2019). Phytochemical Analysis and Assessment of Antibacterial and Antioxidant Activities of Phytolacca dodecandra L. Herit Leaf Extracts (Phytolaccaceae). International Journal of Biomedical Engineering and Clinical Science, 5(3), 31-39. doi: 10.11648/j.ijbecs.20190503.11.

Klopper, R., Smith, F. G. (2013). Aloes of the world: When, where and who? Aloe 50: 44-52. Letsara, R., Rakotoarisoa S.E., Almeda, F. (2012). Three new Aloe species from Madagascar. Malagasy Nature, 6, 46-55.

Lindsey, K.L., Viljoen, A.M., Jager, A.K. (2003). Screening of Aloe species for antioxidant activity. South African Journal of Botany, 69(4), 599-602.

Miladi, S., Mohamed, D. (2008). In vitro antioxidant activities of Aloe vera leaf skin extracts. Journal de la Société Chimique de Tunisie, 10, 101-109.

Mpiana, P.T., Ngbolua, K.N., Tshibangu, D.S.T., Kilembe, J.T., Gbolo, B.Z., Mwanangombo, D.T., Inkoto, C.L., Lengbiye, E.M., Mbadiko, C.M., Matondo, A., Bongo, G.N., Tshilanda, D.D. (2020a). Identification of potential inhibitors of SARS-CoV-2 main protease from Aloe vera compounds: a molecular docking study, Chemical Physics Letters, doi: https://doi.org/10.1016/j.cplett.2020.137751

Mpiana, P.T., Ngbolua, K.N., Tshibangu, D.S.T., Kilembe, J.T., Gbolo, B.Z., Mwanangombo, D.T., Inkoto, C.L., Lengbiye, E.M., Mbadiko, C.M., Matondo, A., Bongo, G.N., Tshilanda, D.D. (2020b). Aloe vera (L.) Burm. F. as a Potential Anti-COVID-19 Plant: A Mini-review of Its Antiviral Activity. European Journal of Medicinal Plants, 31(8), 86-93.

Ngbolua, K.N., Rafatro, H., Rakotoarimanana, H., Urverg, R.S., Mudogo, V., Mpiana, P.T., Tshibangu, D.S.T. (2011a). Pharmacological screening of some traditionally-used 
antimalarial plants from the Democratic Republic of Congo compared to its ecological taxonomic equivalence in Madagascar. Int. J. Biol. Chem. Sci., 5(5), 1797-1804.

Ngbolua, K.N., Rakotoarimanana, H., Rafatro, H., Urverg, R.S., Mudogo, V., Mpiana, P.T., Tshibangu, D.S.T. (2011b). Comparative antimalarial and cytotoxic activities of two Vernonia species: $V$. amygdalina from the Democratic Republic of Congo and V. cinerea subsp vialis endemic to Madagascar. Int. J. Biol. Chem. Sci., 5(1), 345-353.

Ngbolua, K.N., Shetonde, O.M., Mpiana, P.T., Inkoto, L.C., Masengo, C.A., Tshibangu, D.S.T., Gbolo, Z.B., Baholy, R., Fatiany, P.R. (2016a). Ethno-pharmacological survey and Ecological studies of some plants used in traditional medicine in Kinshasa city (Democratic Republic of the Congo). Tropical Plant Research, 3(2), 413-427.

Ngbolua, K.N., Mandjo, B.L., Munsebi, J.M., Masengo, C.A., Lengbiye, E.M., Asamboa, L.S., Konda, R.K., Dianzuangani, D.L., Ilumbe, M., Nzudjom, A.B., Kadimanche, M., Mpiana, P.T. (2016b). Etudes ethnobotanique et écologique des plantes utilisées en médecine traditionnelle dans le District de la Lukunga à Kinshasa (RD du Congo). International Journal of Innovation and Scientific Research, 26(2), 612-633.

Ngbolua, K.N., Inkoto, L.C., Mongo, L.N., Masengo, A.C., Masens Da-Musa, Y.B., Mpiana, P.T. (2019a). Etudes ethnobotanique et floristique de quelques plantes médicinales commercialisées à Kinshasa, République Démocratique du Congo. Rev. Mar. Sci. Agr. Vet., 7 (1), 118-128.

Ngbolua, K.N., Zuangbo, I., Molongo M., Masengo, A.C., Djolu, D.R., Yabuda, H., Bongo, N.G., Gbolo, Z.B., Monde-te-Kazangba, G. (2019b). Effect of Agricultural Residues Based-Compost on the Yield of Amaranthus hybridus L. (Amaranthaceae) in GbadoLite City, Nord-Ubangi (Democratic Republic of the Congo). Budapest International Research in Exact Sciences (BirEx) Journal, 1(4), 53-61.

Ngbolua, K.N., Kumbali N.G., Mbembo-wa-Mbembo, B., Djolu D.R., Bongo, N.G., Falanga, M.C., Gbolo, Z.B., Masengo, A.C., Libwa, M.T.B. (2019c). Epidemio-therapeutic Survey on Malnourished Children Aged 0-5 Years Old in the Gbado-Lite Health Zone (Nord Ubangi Province, Democratic Republic of the Congo). Britain International of Exact Sciences (BIoEx) Journal, 1(1), 22-28.

Ngbolua, K.N., Zuangbo, I., Molongo, M., Masengo, A.C., Djolu, D.R., Yabuda, H., Bongo, N.G, Gbolo, Z.B., Monde, -te-K.G. (2019d). Effect of Agricultural Residues BasedCompost on the Yield of Amaranthus hybridus L. (Amaranthaceae) in Gbado-Lite City, Nord-Ubangi (Democratic Republic of the Congo). Budapest International Research in Exact Sciences (BirEx) Journal, 1(4), 53-61. doi: https://doi.org/10.33258/birex.v1i4.477.

Ngbolua, K.N., Kumbali, N.G., Mbembo-wa-Mbembo, B., Kohowe, P.S., Kogana, K.F., Bongo, N.G., Masengo, A.C., Djolu, D.R. (2020a). First Report on Three Cases of Monkey pox in Nord Ubangi Province (Democratic Republic of the Congo). Britain International of Exact Sciences (BIoEx) Journal, 2(1), 120-125.

Ngbolua, K.N., Ngemale, G.M., Masengo, A.C., Ndolete, G.J.P., Bongo, N.G., Ndanga, B.A., Tshibangu, D.S.T., Tshilanda, D.D. (2020b). Survey on the Sale of Megaphrynium Macrostachyum (Marantaceae) Leaves in Gbado-Lite City and Surroundings (Nord Ubangi Province, Democratic Republic of the Congo). Budapest International Research in Exact Sciences (BirEx) Journal, 2(2), 157-167.

Ngunde-te-Ngunde, S., Lengbiye, M.E., Tshidibi, D.J., Kengo, V.F., Djolu, D.J., Masengo, A.C., Gbolo, Z.B., Iteku, B.J., Mpiana, P.T., Ngbolua, K.N. (2019). Antisickling and Antibacterial Activites of Anthocleista schweinfurthii Gilg. (Gentianaceae) from Nonhuman Primates Pharmacopoeia in Democratic Republic of the Congo. Budapest International Research in Exact Sciences, 1(3), 14-20.

Orlando, G. (2013). Aloes of Madagascar. Aloe, 50, 61-67. 
Rakotoarisoa, S.E., Klopper, R.R., Smith, G.F. (2014). A preliminary assessment of the conservation status of the genus Aloe L. in Madagascar. Bradleya, 32, 81-91.

Randrantoarimbola L., Rafalimanantsoa J., Ratiarimananjatovo N., Randriamanantena A.A., Bongo N., Ngbolua K.N., Robijaona B. (2020). Formulation of Moringa oleifera Lam. based Bio-fortified Food Supplement for Pregnant Women in Madagascar, Indian Ocean. Britain International of Exact Sciences (BIoEx) Journal, 2(2), 533-540. 